Makale Geliş | Received: 30.09 .2019

Makale Kabul | Accepted: 11.10.2019

DOI: $10.18795 /$ gumusmaviatlas.627046

Mavi Atlas, 7(2)2019: 321-337

Araştırma Makalesi | Research Article

\begin{abstract}
Muzaffer BAŞKAYA
Dr. Öğr. Üyesi| Assist. Prof. Dr. Trabzon Üniversitesi, Fatih Eğitim Fakültesi, Türkçe ve Sosyal Bilimler Eğitimi Bölümü, Trabzon-TÜRKIYYE Trabzon University, Fatih Education Faculty, Department of Turkish and Social Studies Education, Trabzon-TURKEY

ORCID: 0000-0002-4593-0979 mbaskaya61@gmail.com
\end{abstract}

\title{
Trabzon İlini Kalkındırma Cemiyeti’nin Kuruluşu Faaliyetleri ve Bu Kapsamda Ortaya Çıkan Bir Mahalle: Kalkınma Mahallesi
}

$\ddot{O} z$

Tarihi İpek Yolu'nun Karadeniz'e çıkış kapılarından biri olan Trabzon, bu özelliği sayesinde oldukça canlı bir ticari hayata sahne olmuştur. Trabzon'un ticari bünyesine zarar veren gelişme 1914 yılında yaşanmış ve Birinci Dünya Savaşı'nın yıkıcı etkisi, başta tarihi İran transit ticareti olmak üzere Trabzon ekonomisini sarsmış ve böylece Trabzon, geri dönülemeyecek bir biçimde ticaret merkezi olma konumunu yitirmiştir. Cumhuriyetin ilanı sonrası kenti eski parlak günlerine döndürmek için bazı projeler ortaya atılsa da değișen şartların da etkisiyle Trabzon, geçmişteki canlı ekonomik yapısını kaybetmiş̧ir. 27 yıllık Tek Parti İktidarı Döneminde beklenen atılımların gerçekleştirilemediğini gören ve doğal olarak ümitsizlik içine düşen Trabzon kamuoyu 1950 yılında yaşanan iktidar değișikliğini bir firsat olarak değerlendirmiștir. Yeni iktidarın yeni bir ekonomik anlayıșla Trabzon'a ve kentin meselelerine sahip çıkacağını ümit eden bir kısım müteşebbis bu konudaki beklentileri daha yüksek bir sesle dile getirmek amacıyla merkezi Ankara'da olmak üzere Trabzon İlini Kalkındırma Cemiyeti adı altında bir örgütlenme içine girmişlerdir. Trabzon’u Kalkındırma Cemiyeti en önemli hamlesini 1956 yılında gerçekleştirmiş ve Değirmendere'de 200 evden oluşan modern bir mahalle kurulmasına karar verilmiștir.

Anahtar Kelimeler: Trabzon, Transit Ticaret, Kalkınma, Cemiyet.

\section{The Establishment Activities of the Development Society of Trabzon Province Its Activities and a Neighborhood: Kalkınma Neighborhood}

\begin{abstract}
Trabzon, which is one of the departure points of the historical Silk Road to the Black Sea, was a lively commercial life scene because of this feature. The development that harmed Trabzon's commercial sector was experienced in 1914 and the destructive effect of the First World War shook the Trabzon economy, mainly the historical Iranian transit trade, and Trabzon thus lost its position as a trade center in a way that could not be reversed. Although some projects were put forward to turn the city into an old bright day after the declaration of the Republic, Trabzon lost its vivid economic structure in the past due to the changing conditions. Trabzon's public opinion that saw the expected breakthroughs could not be performed during the 27-year Single Party rule, fell into despair and saw the power change in 1950 as an opportunity. Some entrepreneurs who hoped that the new government would take on the issues of Trabzon and the city with a new economic understanding entered an organization under the name of the Society of Development of Trabzon Province in central Ankara in order to express this expectation with a higher voice. The Association for the Development of Trabzon made its most important move in 1956 and it was decided to establish a modern neighborhood consisting of 200 houses in Degirmendere.
\end{abstract}

Keywords: Trabzon, Transit Trade, Development, Society. 


\section{Giriş}

Trabzon, Anadolu'nun kuzey doğusunda, Doğu Karadeniz'in doğal bir limanının kıyısında, Asya ve Ortadoğu transit yolunun başında kurulmuş bir şehirdir. Bu itibarla Trabzon eski çağlardan beri batı dünyasının, ihtiyaç duyduğu doğu mallarını elde etmek için kullandığı liman kentlerinden biriydi (Tezcan 2002: 72-74). Trabzon'un transit ticaret noktasında en önemli özelliği ise ünlü İpek Yolu'nun üzerinde bulunmasıydı. Tüm bu özelliklerinin yanında şehrin transit ticaret sahasında sahip olduğu stratejik konumunu güçlendirmek ve limana gelen gemilerin emniyetini sağlamak amaciyla (Kütükoğlu, 1988: 97) Roma İmparatoru Hadrianus döneminde bir mendirek inşa edilmiş (Tekindă̆ 1974: 456-469) ve böylece Trabzon, başta İran ve Azerbaycan olmak üzere, Kafkasya, Türkistan (Orta Asya) ve kısmen de Hindistan'ın batıya açılan en mühim kapısı hâline gelmiştir (Tozlu 2002: 482).

Trabzon'un transit bir merkez oluşu şehrin askerî ve ticari olarak fonksiyonunu önemli derecede arttırdı. Zira Doğu Roma İmparatorluğu zamanında Müslüman Arapların Anadolu'ya yönelik akınlarına hedef olmayan yerler arasında bulunan Trabzon, Müslüman tacirler için Karadeniz ticaretinde önemli bir liman haline geldi (Lowry vd. 2012: 296). Ticari önemini daha sonraki yüzy1llarda da muhafaza eden ve zamanla cazibe merkezi hâline gelen Trabzon'un Türklerin eline geçmesinin ardından, Osmanlı Devleti, özellikle Trabzon-İran transit hattının sağlıklı bir şekilde çalışması için büyük gayret sarf etmiştir. İmparatorluğun en önemli gelir kapılarından biri olan Karadeniz ticareti ve Trabzon-Tebriz transit yolu için en kritik gelişme 1774 yılında yaşanmış ve Küçük Kaynarca Anlaşmasıyla Rus ticaret gemileri ilk defa Karadeniz'de dolaşma hakkını elde etmiş, onları 1784'de Avusturya, 19'ncu yüzyılın başında İngiltere ve Fransa (1802), daha sonra Danimarka ve İspanya takip etmiştir (Yılmaz, 2009: 369). Karadeniz'in uluslararas1 ticarete açılması, buharlı gemilerin Karadeniz'e girişi (Issawi, 1998: 80) ve Sanayi Devrimi'ni gerçekleştiren İngiltere'nin Doğu ticareti için Trabzon'u üs haline getirmesi sonucunda, Trabzon ticareti yeni bir döneme girmiştir. Böylece 19. yüzyılın ortalarında Trabzon, Osmanlı Devleti'nin en önemli ticaret şehirlerinden biri haline gelmiştir. Hatta dönemin Osmanlı arşiv belgelerini inceleyerek 1861'de Türkiye isimli muhteşem bir eser kaleme almış olan Camille Collas'a göre Trabzon, İstanbul'dan sonra Osmanlı'nın en büyük ticaret şehriydi (Collas 1861: 209).

1860'ların ortalarından itibaren Trabzon ekonomisi büyük bir krizin içine girmiştir. Krizin en önemli nedeni, Trabzon-Erzurum-Tebriz yolunun ticarî hacminde yaşanan daralmaydı. Bunda, Rusların İran transit ticaretini tekrar Kafkasya'ya çekmek 
için 1860'tan itibaren yaptıkları hamleler etkili oldu. Daha önce Erzurum üzerinden gerçekleşen Avrupa-Kuzey İran ticareti, önce Poti-Tiflis hattına, 1877-78 Osmanl1-Rus Savaşı'ndan sonra ise Batum-Tiflis güzergâhına kaydı. Rusların Kafkasya'da yaptıkları demiryolları sayesinde İran transit malları, birkaç günlük emniyetli bir yolculukla Karadeniz limanlarına ulaştırılmaya başlandı. Aynı eşya Trabzon-Erzurum-Tebriz karayoluyla yaklaşık 40 günlük meşakkatli bir yolculukla taşınabiliyor; üstelik kervanlar çeşitli dış etkilere ve eşkıya baskınlarına maruz kalıyordu (BCA, 030.10.71.465.1). Bunlara ilave olarak rakip yol ve limanlar çağın gereklerine uygun bir altyapıya kavuşurken Trabzon-Erzurum-Tebriz güzergâhındaki karayolu ve Trabzon Limanı, bir türlü istenilen seviyeye getirilemedi (Diplomatic and Consular Reports on Trade and Finance 1887: 4).

Tüm bu olumsuz gelişmelere karşın belli oranda canlılı̆̆ını koruyan TrabzonTebriz ticaretine son darbe Birinci Dünya Savaşı'nda vurulmuştur. Zira savaş yıllarında Rusların hedef alanı olması dolayısıyla Trabzon Limanı tahrip olmuş, (Öksüz 2006: 396) gerek bombardımanlar nedeniyle yaşanan yıkım gerekse halkın işgal edilmeyen yerlere doğru göçünün meydana getirmiş olduğu sosyal problemler Trabzon'u oldukça derinden etkilemiştir. Savaş sonrasında ortaya çıkan durumu ele alan bir yazar bu konuda yaşanan acıklı durumu şu şekilde tasvir etmiştir: Birinci Dünya Savaşı'na kadar Rusların demir rayları bizim toprak yolu, oradaki lokomotifin h1z1 buradaki devenin sabrını yenememiş̧ken, savaş her şeyi değiştirdi. Kaybolan askerin geri gelişi gibi kaybolan transiti de geri çağırdık. Fakat gürbüz gidip dermansız gelen asker gibi transit de öyle tanınmaz bir halde geldi ki... (Kazgan vd, 1997: 306). Yazarın da ifade ettiği gibi İran transiti yok olmuş, Trabzon-İran yolu yerine Bakü-Batum yolu ön plana çıkmıştır. Savaş dolayısıyla açılan bu güzergâh, İran-Erzurum-Trabzon yolunu köreltmiş ve böylece Trabzon, transit ticaretinde merkez olma konumunu geri dönülemeyecek bir biçimde yitirmiştir (Başkaya 2015: 19).

Cumhuriyetin ilk yıllarına gelindiğinde Trabzon ekonomisi adeta can çekişiyordu. Şehrin ana gelir kapısı durumunda olan İran transit ticareti bitme noktasına gelmiş, Rumlar mübadele ile gönderilmiş, Müslüman yerli tüccarın büyük bir bölümü ise şehri terk etmişti. Buna ilaveten Rize, Ordu ve Giresun'un ayrı bir vilayet haline gelmesi (Küçükuğurlu 2009: 25) nedeniyle idari manada bir küçülme yaşanması, şehri iç bölgelere bağlayacak bir demiryolunun yapılmaması, modern bir limana sahip olunamaması gibi faktörler Trabzon'un ekonomik anlamda yaşadığı çöküşün diğer nedenleri olarak ortaya çıkmıştır. Trabzon ekonomisinin bel kemiği durumunda olan İran 
Muzaffer BAŞKAYA, “ Trabzon İlini Kalkındırma Cemiyeti’nin Kuruluşu Faaliyetleri ve Bu Kapsamda Ortaya Çıkan Bir Mahalle: Kalkınma Mahallesi”, Mavi Atlas, 7(2)/2019: 321-337

transitinin durumunu gösteren aşağıdaki tablo, gelinen noktayı açıkça göstermektedir: (BCA, 030.01./39.233.11.9)

Tablo 1: 1925-1930 Yılları Arasında Transit Ticaret

\begin{tabular}{|l|l|l|}
\hline Sene & Taşınan Mal (Kilo) & Kazanç Kıymet (Lira) \\
\hline 1925 & 6.120 .783 & 16.685 .055 \\
\hline 1926 & 5.554 .327 & 14.282 .485 \\
\hline 1927 & 4.179 .042 & 9.885 .775 \\
\hline 1928 & 3.535 .750 & 13.012 .050 \\
\hline 1929 & 2.607 .400 & 9.450 .800 \\
\hline 1930 & 1.385 .305 & 3.777 .617 \\
\hline
\end{tabular}

İran transitini kaybeden Trabzon ekonomisine bir darbe de Sivas-Erzurum demiryolu hattının açılması vurmuştur (Erzurum Gazetesi, 20 Birinci Teşrin 1939). Böylece Trabzon artık Doğu Anadolu'nun iskelesi olma özelliğini de kaybetmiş ve iyice at1l hale düşmüştür ( $B C A, 030.10 . / 65.433 .4)$. Böylece Modern bir liman ve onu iç bölgelere bağlayacak demiryolu bağlantısı olmadığı için sınırlı bir ihraç merkezi olarak kalan, uluslararası ticaretteki kilit nokta olma özelliğini yitiren Trabzon Limanı artık sadece findık, tütün, yumurta, fasulye, sadeyağ gibi yerel ürünler veya Doğu Anadolu Bölgesi’nden şehre gelen canlı hayvanların ihraç edildiği bir iskele görünümü kazanmıştır (Başkaya 2014: 20).

19. yüzyılda Anadolu'nun en işlek ticaret merkezlerinden biri iken Cumhuriyetin ilk yıllarında sadece fındık ve tütün gibi tarım ürünlerinden gelecek gelire bel bağlar duruma gelen Trabzon ekonomisini canlandırmak için çeşitli adımlar atılmıştır. ${ }^{1}$ Fakat 27 senelik tek parti iktidarı yıllarında yapılan çalışmalara rağmen Trabzon ekonomisi eski canlılığına kavuşamamıştır. 1950 yılına gelindiğinde Türkiye'de iktidar değişimi yaşanmış ve daha liberal bir ekonomik anlayışa sahip Demokrat Parti işbaşına gelmiştir. $\mathrm{Bu}$ değişimi firsata çevirmek için harekete geçen Trabzonlular, kentin geri kalmışlığına

\footnotetext{
${ }^{1}$ Günden güne geriye giden Trabzon ekonomisini canlandırmak amacıyla harekete geçen Cumhuriyet Hükumeti, temelleri meşrutiyet dönemine dayanan bir projeyi raftan indirmiş ve Trabzon ile Erzurum arasında demiryolu inşa edilmesi için çalışmalara başlanmıştır (Ístikbal Gazetesi, 1 Nisan 1340/1924). Bu kapsamda ilk olarak işin yasal zemini oluşturulmuş ve 10 Nisan 1924 tarihinde TBMM'de TrabzonErzurum Demiryolları ile Trabzon Limanı Keşfiyat ve İhrazatının 1340 Senesi Zarfında İcrası hakkında 476 sayılı kanun çıkarılmıştır(Istikbal Gazetesi, 21 Nisan 1340/1924).
} 
bir çözüm bulabilmek amacıyla merkezi Ankara'da olmak üzere Trabzon İlini Kalkındırma Cemiyeti'ni kurmuştur. Cemiyet kısa süre sonra Trabzon'da da bir şube açmış ve kentin sorunlarını yetkili makamların dikkatine sunmuştur. Cemiyetin yaptığı faaliyetlerden bir kaçını saymak gerekirse, Cumhurbaşkanı Bayar Çankaya'da ziyaret edilmiş, raporlar kaleme alınmış, kitap vesaire yayınlar yapılmış, davet ve organizasyonlar tertip edilmiştir. Cemiyet, 1956 yılında Trabzon'un doğu yakasında boş bulunan bir bölgede kooperatif şeklinde bir mahalle kurulması için harekete geçmiş, Trabzon'un en varlıklı ailelerinin katılımıyla bugün şehrin en işlek yerlerinden biri olan Kalkınma Mahallesi kurulmuştur.

Belge tarama yöntemi ile hazırlanan bu çalışmada söz konusu Cemiyetin kuruluşu, gelişimi, belli başlı faaliyetleri ve Kalkınma Mahallesi’nin teşkili ele alınmıştır. Çalışmada bilhassa Trabzon' da yayınlanan dönemin yerel gazetelerinden istifade edilmiş ayrıca arşiv belgeleri ve diğer kaynak eserlerden de yararlanılmıştır.

\section{Trabzon İlini Kalkındırma Cemiyeti’nin Kuruluşu}

14 Mayıs 1950 günü yapılan seçimler Türk siyasi hayatından büyük bir değişimi de beraberinde getirmiştir. Zira o döneme kadar 27 yıl boyunca iktidarda kalan Cumhuriyet Halk Partisi (CHP), bu seçimde büyük bir mağlubiyet alarak iktidarı Demokrat Parti'ye (DP) devretmiştir (Cumhuriyet Gazetesi, 15 Mayıs 1950). Seçim sonuçları Türkiye'de her yönüyle yeni bir dönemin başlangıcı anlamına geliyordu. Tek Parti İktidarı boyunca Ankara'dan gerekli desteği göremediğini, şehrin ihmal edildiğini düşünen bir grup Trabzonlu, merkezi Ankara'da olmak üzere 6 Şubat 1952 tarihinde Trabzon İlini Kalkındırma Cemiyeti'ni kurmuşlardır. Cemiyetin kuruluş gayesi ana nizamnamesinin ikinci maddesinde; Trabzon ilinin kültürel ve iktisadi kalkınmasını temin için inceleme ve araştırmalar yapmak, varılacak neticeleri ilgililere ve umumi efkâra arz etmektir şeklinde ifade edilmiştir. Cemiyetin kuruluş amacı Trabzon basınına şu şekilde yansımıştır (Yeniyol Gazetesi, 27 Mayıs 1952):

...gayesi, Trabzon İlinin kültürel, iktisadi, ticari, sıhhi, bedii kalkınmasına önayak olmak ve günden güne sönen bu güzelim yurt parçasının dertlerine yaralarına çareler aramaktır. Cemiyetimiz bir tetkik ve araştırma enstitüsü olacaktır. Bütün gayelerimizin bir tek cümleye sığdırılabilecek özeti budur. $\mathrm{Bu}$ cemiyet bir banka değildir, fakat Trabzon'dan yetişmiş ilim ve irfan sahipleri, manevi yardımlarını esirgemezlerse Trabzon'un mükemmel bir tarihini yazdırabilir, bu günkü kötü gidişinin sebeplerini kesin istatistiklerle belirtebilir, küçük sanayinin inkişaf çarelerini tetkik ettirebilir ve yayınlayabilir, barsak parazitleri, verem gibi hastalıklarla daha verimli savaş usullerini ilmi tarzda etüt ettirip, projeler hazırlatılabilir, Trabzon ilini turistik bakımdan tanıtabilir, 
broşürlerle fotoğraf sergileri ile sinema filmleri ile seyyahlar cezbedilebilir. Hatta Trabzon'da kurulabilecek bir çimento fabrikasının, balık konservesi sanayinin etüt ve projelerini pek cüzi bir masraf ihtiyar etmek şartıyla yaptırabiliriz.

Ankara'da kurulan cemiyetin nizamnamesine bakıldığında şehrin her anlamda kalkınmasını sağlamak amacıyla hemen her türlü enstrümanın devreye sokulması amaçlanıyordu. Basın-yayın faaliyetlerinden, turizme, çimento fabrikasının tesisinden, küçük el sanatlarına kadar Trabzon'un kalkınması için hemen her çareye başvurulması gerektiğine işaret ediliyordu. Cemiyetin kuruluşundan bir kaç ay sonra "Ankara'dan Mektuplar" başlığı ile bir yazı kaleme alan Kemal Karadenizli söz konusu Cemiyetin kuruluş gayesi ile ilgili şu bilgileri vermiştir (Yeniyol Gazetesi, 30 Mayıs 1952):

İktisadi bir mezhebin menşe ve meşheri olan bu belde Hindin kuzey yollarına giden deniz kapısının kilit noktası idi. Bugün bir ticaret ve transit şehri olmak vasfını kaybetmiş, sönmeye yüz tutmuştur. Halkı ile tabiatıyla yurdumuzun en hoş ve orijinal köşelerinden bir olan Trabzon şimdiye kadar en fazla ihmal edilmiş bir beldemiz sayılabilir. Güngörmüş asil Trabzon'un bu hale düşmesi böyle ihtişam içinde erimesine tahammül edilemiyor. Onu düştüğü bu talihsizlikten kurtarmak ancak iktisaden kalkındıracak tedbirler almakla olacaktır.

Trabzon'u Kalkındırma Cemiyeti'nin merkezinin Ankara'da bulunduğu günlerde yaptığı en önemli hamle Trabzon'da yeni bir bankanın tesisi için harekete geçmekti. Halk Bankası'nın Trabzon'da bir şube açması için çaba sarf eden cemiyet üyeleri, Trabzon Ticaret ve Sanayi Odasını devreye sokarak bankanın sermayesi oluşturulurken 20.600 liralık bir tutarı toplamış ve bankanın sermayesine yatırmışlardır (Yeniyol Gazetesi, 15 Haziran 1952). Tüm bu gelişmeler yaşanırken Trabzon'un önde gelen gazetelerinden olan Yeniyol Gazetesi ise bir köşesini Cemiyetin faaliyetlerine ayırmıştır. Bu köşede Trabzon'un ve bu itibarla Doğu Karadeniz sahilinde bulunan vilayetlerin kalkınmaları için ne gibi tedbirlere başvurulması gerektiği ele alınmıştır. Trabzon İlini Kalkındırma Cemiyeti Köşesi adıyla bilenen bu sütunda Rize'de yeni yeni başlayan çay üretiminin durumu, Giresun ve Ordu'da fındığın daha etkili bir geçim aracı haline getirilmesinin çareleri üzerinde durulmuştur (Yeniyol Gazetesi, 19 Haziran 1952).

Faaliyetlerine Ankara'da devam eden Trabzon İlini Kalkındırma Cemiyeti, 1952 yılının ortalarından itibaren Trabzon'da bir şube açmak için harekete geçmiştir. Cemiyetin Genel Sekreteri Muvaffak Akman, Trabzon'a gelerek, şehirde yapılacak kongrenin hazırlıkları ile meşgul olmuştur (Yeniyol Gazetesi, 12 Temmuz 1952). Yapılan hazırlıklar sonunda Ağustos 1952'de söz konusu cemiyetin Trabzon şubesi kurulmuştur. Cemiyetin ilk müteşebbis heyeti şu kişilerden oluşuyordu: Muzaffer Korlu, Avukat Vehbi 
Dranaz, Şevket Çulha, Dr. Ahmet Özpeker, Zeki Yağmurdereli, Mühendis Mehmet Cinel, Mühendis Enver Tüzünsoy, Fikri Karanis ve Cumhur Odabaşığlu. Trabzon İlini Kalkındırma Cemiyeti'nin Ana Nizamnamesinde cemiyetin kuruluş gayesi şu şekilde ifade edilmiştir (Yeniyol Gazetesi, 1 Ağustos 1952) :

Madde 2: Mevzuu ve gayesi Trabzon ilinin kültürel ve iktisadi kalkınmasını, sağlık durumunun düzelmesini temin için inceleme ve etütler yapmak, varılacak neticeleri ilgililere ve umumi efkâra arz etmek, mahallinde halledilebilecek dertlere cemiyet eliyle çareler bulmaktır. Bu gayelere ulaşmak için konferanslar tertip etmek, neşriyat yapmak, vatandaşları broşürler film vs. ile aydınlatmak gibi yollardan faydalanılacaktır.

Trabzon'da da teşekkül eden Cemiyetin, kısa süre sonra kongresini yapmak için hazırlıklara başlanmıştır. Yapılacak kongreyi yönetmek üzere Ankara'daki şube Başkanı Kemal Karadenizli Trabzon'a gelmiş ve bazı temaslarda bulunmuştur (Yeniyol Gazetesi, 28 Ağustos 1952). Cemiyetin kuruluş hazırlıkları ve yapılan çalışmalara bakılırsa Ankara'dan gelen Kemal Karadenizli başkanlığında, yapılacak olan kongrenin tertip ve idaresiyle meşgul olmak üzere Ankara ve Trabzon'daki kalkındırma cemiyetleri idare heyetlerinden oluşan bir tertip komitesi kurulmuştur (Yeniyol Gazetesi, 6 Eylül 1952). Yapılan çalışmalar neticesinde Trabzon'u Kalkındırma Cemiyeti'nin ilk yönetim kurulu toplantısı yapılmıştır. 5 Eylül 1952 günü Trabzon Belediyesi'nde yapılan toplantıda vazife taksimi yapılarak idare heyeti başkanlığına Belediye Başkanı Muzaffer Korlu, İkinci Başkanlığa Dr. Ahmet Özpeker, Genel Sekreterliğe Müteahhit ve Gazeteci Şevket Çulha, İdare Amiri yüksek mühendis Mehmet Cinel, muhasip veznedar üyeliğe Tüccar Fikri Karanis diğer üyeliklere gazeteci Zeki Yağmurdereli, avukat Vehbi Dranas, nakliye acentecisi Cumhur Odabaşığlu, yüksek ziraat mühendisi Enver Tüzünsoy seçilmiştir (Yeniyol Gazetesi, 6 Eylül 1952).

Trabzon'u ekonomik manada eski günlerine döndürmek amaciyla kurulan Cemiyet, 1952 yılı Eylül ayında vilayet genelinde büyük bir kongre tertip etmeyi amaçlamış ve bu konuda il genelinde büyük bir seferberlik başlatılmıştır. Buradaki amaç, şehrin sorunlarını kapsamlı bir şekilde ele alarak ses getirici bir kongre gerçekleştirip, Ankara'nın dikkatini çekmekti. Cemiyet, kongreye katılımı artırmak için bazı tedbirler almış, komisyonlar kurularak şehrin sorunlarıyla ilgili fikri olan herkes bu kongreye çağrılmıştır (Yeniyol Gazetesi, 9 Eylül 1952). Kongre toplanmadan evvel yerel basına bazı açıklamalarda bulunan Kemal Karadenizli kongre ve cemiyetin gelişimiyle ilgili şu değerlendirmelerde bulunmuştur (Yeniyol Gazetesi, 13 Eylül 1952): 


\begin{abstract}
Bir şehir pis ise kabahat o şehri idare edenlerde değil orada oturanlardadır. Eğer Trabzon vilayeti iktisaden gerilemiş ve çökmeye yüz tutmuş ise sebep, Trabzonluların yine kendimizin bu vilayete karşı alakasızlığıdır...Trabzonlu tüccarlarımız bilmelidir ki, bu vilayete karşı bir takım vazifeleri vardır. Kalkınma topyekûn çalışılırsa olur. ...Trabzon'un gittikçe felce uğrayan iktisat ve iş hayatını yeniden kurarak geliştirmek ve kalkınma davasını gerçekleştirmek için ne yapmak lazım geldiğini tespit etmek ve böylece Trabzon'un kalkınma programını tanzim etmek üzere bu ay içerisinde şehrimizde Trabzon Vilayeti Kalkınma Kongresi yapmayı cemiyetimiz idare heyeti Ankara'da kararlaştırmıştır.
\end{abstract}

Trabzon'un sorunlarının ele alınacağı Trabzon Vilayeti Kalkınma Kongresi öncesinde daha önceden oluşturulan komisyonlar, 15 Eylül 1952 günü toplanmaya başlamıştır. Komisyonlarda genel olarak hidroelektrik santralinin tesisi, Trabzon' da Halk ve Merkez Bankası'nın kurulması, Denizciler Bankası'nın açılması, İran transitinin tekrar canlandırılması, balık ve konserve sanayinin açılması, madenciliğin geliştirilmesi gibi hususlar ele alınmıştır (Yeniyol Gazetesi, 18 Eylül 1952). Komisyon toplantılarının tamamlanmasının ardından Vilayet Kalkınma Kongresi 26 Eylül 1952 günü Trabzon’daki Sümer Sineması binasında toplanmıştır. Kongrenin gündemi 4 başlıktan oluşmuştur.

1.Ziraat işleri ve köycülük

2.Şehircilik ve yapı turizm

3.İktisadi işler

4.Sağl1k ve sosyal işler

Trabzon'un ileri gelen iş insanları, milletvekilleri, müteşebbislerinin bir araya geldiği Vilayet Kalkınma Kongresi'nde kongre başkanlığına Vali Yarımcısı Fahri Tokmakçıŏlu, divan kâtipliklerine Öğretmen Ömer Akbulut ve Tüccar Fikri Karanis seçilmiştir. Kongrede, daha önce ilgili komisyonlar tarafından hazırlanan raporlar birer birer okunmuş, yapılan müzakerelerin ardından tespit edilen kararlar Trabzon Kalkınma Programı adyla bir başlık altında toplanmıştır. Böylece Trabzon'un kalkınma programı da oluşturulmuştur. Son olarak kongre başkanı Vali Yardımcısı Fahri Tokmakçıoğlu, bu kongrenin Trabzon'da ilk, Türkiye'de ikinci kez yapıldığını belirtmiş, kongreyi tertip edenleri tebrik etmiştir (Yeniyol Gazetesi, 11 Aralık 1952). Kongre sonunda yayınlanan raporlara bakıldığında yukarıda verilen 4 başlık altında oldukça uzun ve ayrıntılı tespitler yapıldı ğ görülmüştür.

Trabzon'u Kalkındırma Cemiyeti bir yandan kentin sorunları ile ilgili kongreler toplayıp raporlar kaleme alırken diğer yandan da halkın cemiyete desteğini sağlamak 
amacıyla davetiyeler veya uyarıcı broşürler neşretmiştir. Söz konusu broşürlerden birinde şu ifadelere yer verilmiştir (Yeniyol Gazetesi, 19-20 Ekim 1953) :

Trabzon İlini Kalkındırma Cemiyetinden:

Her vatandaş cemiyette hayırlı işlerin yapılmasında ve faydalı kurumların kurulmasinda kendisini vicdanen mesul, vazifedar tutmak mecburiyetinde olduğunu milli ve insani bir borç bilmelidir.

En büyük içtimai çöküntü ve milli felaket hiç şüphe yoktur ki, israf, lüks, fantezi, içki, kumar ve fuhuştur. Çünkü akıbeti ailenin çökmesi demektir.

Mesut millet, okuma aşkını şiar edinen millettir.

Ey Trabzonlu gençler; sizin vazifeniz yalnız ayak darbesiyle topu yükseklere uçurmak değil, Türk milletinin haysiyet ve şerefini yükseltmektedir. Sevgili Trabzon'u her hususta terakki ettirmeye, her tarafta esenliği ve mutluluğu artırmaya çalışmak da olmalıdır.

Bize Trabzon'u iktisadi, ticari sanayi ve ahlaki bakımlardan yükseltmek için çalışan gençler lazımdır.

1952 yılında kurulan Ankara ve Trabzon'da şubeler açan ve Trabzon'u Kalkındırma Kongresi toplayarak adını duyuran Trabzon'u Kalkındırma Cemiyeti, bu çalışmalarının yanı sıra en fazla ses getiren faaliyetini 1953 yılı sonlarında gerçekleştirmiştir. Cemiyet üyeleri, yaptıkları çalışmalar hakkında bilgi vermek ve bundan sonrası için fikir alış verişinde bulunmak amacıyla Cumhurbaşkanı Celal Bayar'1 Çankaya'da ziyaret etmiştir. Cemiyet Reisi Kemal Karadenizli, bu kabulde ilk olarak cemiyeti tanıtan bir sunum yapmış, ardından cemiyetin çalışmaları hakkında bilgiler vermiştir. Karadenizli, cemiyetin 1952 yılı sonunda Trabzon'da bir kalkınma kongresi topladığını, kongre kararlarının bir kitap haline getirilip basıldığını ifade ederek bu eseri Bayar'a takdim etmiştir. Bunun yanı sıra cemiyetçe bastırılan Trabzon'un fethi, Trabzon'un şairleri ve cemiyetin takvimini yine Bayar'a sunmuştur. Ardından Cumhurbaşkanı Bayar'a Trabzon'un içinde bulunduğu durumla ile ilgili olarak bir izahat vermiştir. Görüşme sonrasında Trabzon heyeti Bayar'ın ilgisinden memnun kalmış, hatta ertesi günü Halk Bankası Umum Müdürü ile görüşmeye giden heyetin burada Bayar'ın Trabzon'da bir Halk Bankası kurulması yönünde bir direktif verdiğini öğrenmiştir (Yeniyol Gazetesi, 19 Kasim1953).

Trabzon'u Kalkındırma Cemiyeti'nin Cumhurbaşkanı Celal Bayar ile görüşmesinin etkileri kısa sürede hissedilmeye başlanmıştır. Zira görüşmenin üzerinden 1 ay geçmeden Trabzon'da Türk Ticaret Bankası bir şube açmaya karar vermiş, 23 Aralık 
günü adı geçen bankanın Trabzon'da bir şubesi faaliyete geçmiştir (Yeniyol Gazetesi, 16 Aralık 1953).

Henüz 2 yıllık bir cemiyet olarak adını ülke gündemine taşımayı başaran Trabzon'u Kalkındırma Cemiyeti zamanla Karadeniz'deki diğer vilayetlerde de şubeler açmaya başlamıştır. Cemiyetin Zonguldak şubesi 1954 yılının sonlarına doğru açılmış ve İdare Heyeti Reisliğine Ziraat Bankası Müdürü Hazım Gürsu seçilmiştir (Yeniyol Gazetesi, 29 Ekim1954).

10 Ekim 1958 tarihinde Trabzon'u Kalkındırma Cemiyeti'nin Trabzon Şubesi, Cemiyetin binasında yıllık kongresini yaparak idare heyetini seçmiş ve İdare Heyeti Reisliğine Burhan Kulaç getirilmiştir. Cemiyetin başkanı olan Kemal Karadenizli bu kongrede yaptığı konuşmada, Trabzon'un dert ve davaları üzerinde durarak, halkın ilgisizliğinden yakınmış ve Trabzon'da aşırı futbol hastalığı ve kahvehane kültürünün yaygınlığını eleştirmiştir. Cemiyet, Trabzon Halk ve Emlâk Kredi Bankalarının, ithalat ve ihracat şirketinin ve 200 evden oluşan Kalkınma Yapı Kredi Kooperatifi'nin kuruluşlarında önemli rol üstlenerek, Trabzon'un çay yetiştirilme bölgesi içerisine alınmasına yardımcı olmuştur. Trabzon Kalkınma Derneği ayrıca Kızılay ve Trabzonlu yüksek tahsil öğrencilerine yardımlarda bulunmuştur. Kemal Karadenizli, Cemiyetin yapacağı işlerle ilgili olarak en önemli meselenin balıkçılık mevzusu olduğunu ifade ettikten sonra, hem balıkçılık hem de çay konusunun görüşüleceği bir toplantı yapılması ve çay ekicileri ile balıkçılara kredi temin edilmesi gerektiğini belirtmiştir. Bunun için de, birer kooperatif kurulması planlanmıştır. Ayrıca Trabzon gibi bir sahil şehrinde plaj olmamasının büyük bir eksiklik olduğu, şehrin sivrisinek ve temizlik gibi birçok sorunu üzerinde durulmuştur (Arslan, 2011: 113).

Cemiyet bunlar dışında Trabzon'un elektrik sıkıntısını gidermek için Değirmendere Hidroelektrik Santrali projesini hazırlamış ve adı geçen proje İller Bankası tarafından ihaleye çıkartılmıştır. Projeye göre ilerde şehrin elektrik ihtiyacının artması durumunda Rize İkizdere Santrali ile Değirmendere Santrali bir hava hattı ile bağlanacak ve bu hat Giresun'a kadar uzatılacaktı. Ayrıca Trabzon'da bir teknik üniversite kurulması konusunda da Cemiyet'in maddi ve manevi destekleri olmuştur (Çaykara Gazetesi, 25 Temmuz 1956).

Trabzon'u Kalkındırma Cemiyeti'nin kuruluş yıllarında el attığı mevzulardan biri de şehrin tarihinin yazılması meselesi idi. Zira o güne kadar Trabzon tarihini derli-toplu bir şekilde ele alan bir eserin bulunmadığını gören cemiyet üyeleri bu konuda harekete geçmiştir. Yerel basında yer alan konuyla ilgili bir haberde, Trabzonlu tarih profesörleri 
mevcut olmasına rağmen vilayetin tarihinin merhum Şakir Şevket'in 76 sene evvel ele aldığı bir esere mahkûm kaldığı belirtilmiştir. Bu duruma çare bulmak isteyen cemiyet üyeleri, Şakir Şevket'in eserini sadeleştirerek halkın daha kolay anlayacağı bir Trabzon Tarihi'nin yazılması için çalışmalar başlatmıştır (Yeniyol Gazetesi, 11 Şubat 1955).

\section{Trabzon'un Doğusunda Kurulan Bir Mahalle: Kalkınma Mahallesi}

Trabzon'u Kalkındırma Cemiyeti'nin Trabzon şehrinin ekonomik ve sosyal sorunlarına çare bulabilmek amacıyla yaptığı faaliyetler arasında en fazla önce çıkanı şehrin doğusunda oluşmasına vesile olduğu ve bugün kentin en önemli yerleşim merkezlerinden biri olan Kalkınma Mahallesi'nin kurulmasıdır. Cemiyet bu teşebbüsü ile o dönemlerde şehrin en önemli meselelerinden biri olan mesken sıkıntısına çare bulup yeni bir istihdam alanı yaratmayı amaçlamıştır.

Cemiyet, şehrin uygun bir yerinde 200 evli modern bir mahalle kurma kararını verdikten sonra ilk iş olarak kendi bünyesi içinde bir Yapı Kooperatifi tesis etmiştir. Bu kooperatifin kanuni formalitesi 1955 yılı Kasım ayı içinde tamamlanmış ve Bakanlar Kurulu'nun 16.11.1955 tarih ve 4.6684 sayılı kararı ile bu proje hükümetçe tasdik olunmuştur. Söz konusu kooperatifin kurucu heyetinde Akif Saruhan, Haluk Çulha, Kemal Karadenizli, Nevzat Hakyemez, Y. Ziya Yenel, Sami Hatipoğlu, Harun Özyılmaz ve Ali Keçeci yer almıştır. Kurulması planlanan mahalle, Değirmendere mevkiinde Trabzon-Rize yolunun Zefanos yolu kavşağı civarında, Değirmendere Köprüsüne 100 metre mesafede bulunan araziden beher eve 250 metrekaresi isabet etmek üzere $200 \mathrm{ev}$ ve mahalle için gerekli çarşı, sinema, garaj da dâhil olmak üzere lazım gelen miktar arazinin satın alınması yoluyla teşkil edilmişstir. Kooperatif usulü ile hemen üye kaydına başlanan mahalle için Trabzonlular büyük bir ilgi göstermiş ve ilk anda 126 kişi kooperatife aza olabilmek için müracaat etmiştir. Daha sonra 60 kişi daha aynı şekilde üye olmak için gerekli meblağı yatırmış ve böylece toplam üye sayısı 180'i aşmıştır ve hedeflenen rakama yani 200'e iyice yaklaşılmıştır. Yerel gazeteler söz konusu tutarı yatıran kişilerin adlarını listeler halinde gazetelerde neşretmiş ve böylece şehirde bu konuda bir farkındalık yaratılması hedeflenmiştir (Doğu Gazetesi, 7 Şubat 1956).

Kalkınma Mahallesi'nin oluşturulacağını haber alan Trabzon halkının, söz konusu projeye büyük bir destek verdiğini ifade etmiştik. Bundan cesaret alan Cemiyet üyeleri ilk hedef olan 200 ortak sayısını artırarak 300'e çıkarmıştır (Doğu Gazetesi, 17 Şubat 1956). Bu arada Cemiyet'te de görev değişikliği yaşanmış ve 1956 yılında yapılan kongrede cemiyetin Trabzon Şubesi Başkanlığına Enver Kölemenoğlu, Umumi Kâtipliğe 
Yusuf Ziya Yenel, Muhasipliğe İhsan Sabır, Veznedarlığa Mahmut Macit, Azalıklara da Hasan Bingöl, Osman Peker, Enver Tüzünsoy seçilmiştir (Doğu Gazetesi, 30 Mart 1956).

Kongre sürecini atlatan Cemiyet hemen Kalkınma Mahallesi'nin kurulması çalışmalarına hız vermiştir. Yapılan çalışmaları denetlemek amacıyla Cemiyet Başkanı Kemal Karadenizli Temmuz ayı ortalarında Trabzon'a gelmiştir. Yaşanan gelişmeler yerel basına şu şekilde yansımıştır(Doğu Gazetesi, 24 Temmuz 1956):

Şehrimizde tesis edilmekte bulunan Kalkınma Mahallesi hakkında aldığımız malumata göre; Vilayetin mesken mevzuunu halletmek ve şehrin imarına yardım etmek gayesiyle cemiyetimiz geçen sene Temmuz ayında Trabzon'un ilk yapı kooperatifi olan "Trabzon Kalkınma Cemiyeti Yapı Kooperatifi'ni” kurmuş ve Değirmendere mıntıkasında 80 dönüme yakın araziyi satın alarak mülkiyetine geçirmiştir. 200 ortağını bugün arsa sahibi yapan kooperatif ev inşaatına başlamak üzere çalışmalarına devam etmektedir. Bu mıntıka Belediye ve Vilayetin yakın alakalarıyla şehir hudutları içine alınmış ve şimdi parselasyonu yapılmakta ve evlerin maliyet hesabı çıkarılmakta ve bankadan para alma muameleleri ikmal edilmektedir. Bu mıntıkada kurulacak olan plaj ve gazinosu olan Kalkınma Mahallesi'ne Trabzonluların gösterdikleri sıcak alaka hala devam etmekte ve 100 asil ortaktan başka 100 Trabzonlu daha ortak kaydedilmiştir. İlk firsatta bunlar için de arsa temin edilecektir.

Trabzon'u Kalkındırma Cemiyeti'nin öncülüğünde oluşturulan Kalkınma Mahallesi projesi, o yıllarda ev sıkıntısı yaşanan Trabzon'da büyük bir ilgi uyandırmıştır. Zira mahallenin kurulması için para yatıran ve kooperatife üye olan kişilere baktığımızda halkın her tabakasından insanların üye yazıldığı görülmekle birlikte adı daha sonra Türkiye ve Trabzon'un gündemine sıç̧a gelecek Ali Osman Ulusoy, Orhan Karakullukçu, Nesip Yağmurdereli gibi simaların da bu oluşuma katkı verdikleri görülmüştür.

Kalkınma Mahallesi'nin kuruluşu ile ilgili ortaya atılan bir iddiaya göre mahallenin ortaya çıkışında Akif Saruhan büyük gayret göstermiştir. Trabzon Ticaret Lisesinde Fransızca öğretmenliği yapan Saruhan, amacı ortaklarını ev sahibi yapmak olan bir kooperatif kurulmasına yardımcı olmuş ve bu işin başına geçmiştir. "Kalkınma Kooperatifi" adıyla faaliyete geçen kooperatif için arsa arayan Akif Saruhan, FaikaNecdet Karaali'ye ait arsaya göz dikmiştir. İlk anda arsayı satın alamasa da daha sonra Akif Saruhan'a bu arsa satılmıştır. Kooperatif, pek başarılı olmasa da Akif Saruhan bu arsayı parselleyip satmış ve mahalle işte bu arsa üzerinde kurulmuştur (Aydın, 2011: 2526) 
Kalkınma Mahallesi'nin kurulmasının ardından 1967 yılında aynı mahallede Karadeniz Teknik Üniversitesi Kampüsü de inşa edilmeye başlanmıştır. Böylece adeta bir şantiye görünümüne bürünen mahalleye 1969 y1lına gelindiğinde dahi sağlıklı şekilde bir su tesisatı kurulamamıştır. Bu mesele ile ilgili Trabzon Belediyesi'nde yapılan bir toplantıda Kalkınma Mahallesi'nin bundan 10 yıl önce belediye hudutları dâhiline alınmasına rağmen bu mahalleye su verilmediği ifade edilmiştir (Trabzon Belediye Zabitları, 24 Aralık 1969).

\section{Sonuç}

Bulunduğu konum itibarıyla Doğu Karadeniz' in en önemli iskelelerinden biri olan Trabzon'un ekonomik durumu 19. yüzyılın sonlarından itibaren kötüleşmeye başlamıştır. Birinci Dünya Savaşı'nın ardından eski parlak günlerini kaybeden Trabzon ekonomisini tekrar canlandırmak için Cumhuriyetin ilk yıllarında bazı adımlar atılmıştır. TrabzonErzurum demiryolu projesi, modern bir liman tesis esilmesi, balıkyağı ve balık sanayinin kurulması, gibi fikirler bir türlü hayata geçirilememiştir. Neticede günden güne kan kaybeden Trabzon ekonomisini eski günlerine döndürmek isteyen bir grup müteşebbis 1952 yılında Trabzon İlimi Kalkındırma Cemiyeti adıyla bir dernek kurmuşlardır. Söz konusu dernek o dönemin liberal ekonomik anlayışının da tesiri ile Trabzon'un o güne kadar unutulmaya yüz tutan ekonomik ve sosyal birçok sorununa el atmaya çalışmıştır.

Trabzon'u Kalkındırma Cemiyeti'nin kongre ve toplantılarında ortaya atılan fikirlere bakıldığında şehrin genel durumu ile ilgili bazı tespitler yapıldığı görülmüştür. $\mathrm{Bu}$ tespitlerde Trabzon halkının üretmekten ziyade tüketmeye alıştı̆̆ 1 , futbola aşırı önem verdiği buna karşın diğer hayati meselelere aynı ilgiyi göstermediği, şehrin sorunlarına duyarsız kaldığı gibi eleştiriler getirilmiştir. Bu nedenle kalkınmayı sadece ekonomik manada değil sosyal, kültürel kısacası bir zihniyet devrimi ile gerçekleştireceklerini öne süren Cemiyet üyeleri, gayet iddialı olan bu tezlerini başarıya ulaştırmak için var güçleriyle çalışmıştır.

Trabzon'u Kalkındırma Cemiyeti geride günümüze ulaşan birçok eser bırakmıştır. Cemiyetin çıkardığı kitap, dergi, davetiye, broşür gibi vesikalar bugün tarihçiler için değerli bir belge olarak varlığını sürdürmektedir. Fakat Cemiyetin asıl mirası Trabzon'un bugün en kalabalık semtlerinden biri olan Kalkınma Mahallesidir. İçinde Karadeniz Teknik Üniversitesi'nin de bulunduğu bu mahalle Cemiyetin bugüne ulaşan en önemli mirasidir.

1952 yılında kurulan Trabzon'u Kalkındırma Cemiyeti’nin hızı 1960 müdahalesi ile kesilmiştir. Zira Cemiyet üyelerinin birçoğunun DP'ye yakın kişilerden oluşması, bu 
Muzaffer BAŞKAYA, “ Trabzon İlini Kalkındırma Cemiyeti'nin Kuruluşu Faaliyetleri ve Bu Kapsamda Ortaya Çıkan Bir Mahalle: Kalkınma Mahallesi”, Mavi Atlas, 7(2)/2019: 321-337

sonucu beraberinde getiren en önemli husus olmuştur. Cemiyetin fesih tarihini tam olarak tespit edemesek de 2000'li yılların başında Trabzon Belediyesi'nde ulaştı̆ıııı bir evrakta Trabzon'u Kalkındırma Cemiyeti'nin adına rastlamadık. Bu da Cemiyetin 1960 müdahalesinden sonraki süreçte feshedilmiş olma ihtimalini akla getirmektedir.

\section{Kaynakça}

\section{Arşiv Belgeleri ve Süreli Yayınlar}

Başbakanlık Cumhuriyet Arşivi, Fon Kodu: 030.10 Yer No: 71.465.1

Başbakanlık Cumhuriyet Arşivi, Fon Kodu: 030.01 Yer No: 39.233.11.9

Başbakanlık Cumhuriyet Arşivi, Fon Kodu: 030.10 Yer No: 65.433.4.

Diplomatic and Consular Reports on Trade and Finance, Turkey, Report for the Year 1886 on the Trade of the Vilayet of Erzeroum, London, 1887.

Erzurum Gazetesi

Cumhuriyet Gazetesi

Çaykara Gazetesi

Doğu Gazetesi

İstikbal Gazetesi

Yeniyol Gazetesi

Trabzon Belediyesi Zabitları

\section{Araştırma Eserleri}

ARSLAN, Zehra, (2011) “Demokrat Parti Döneminde Trabzon 1950-1960”, KTÜ Sosyal Bilimler Enstitüsü, Doktora Tezi, Trabzon.

AYDIN, Ertuğrul, (2011) Trabzon'un B Kapısı Kalkınma, İstanbul: Heyemola Yayınları.

BAŞKAYA, Muzaffer, (2014) "Tek Parti İktidarı Döneminde Trabzon Ekonomisi 1923-1950”, KTÜ SBE Dergisi, Say1 7, ss.17-32, Trabzon.

, (2015) Cumhuriyetin Illk Yllarında Trabzon'da Ekonomik Hayat (1923-1950), Trabzon: Serander Yayınları.

COLLAS, M.B.C. (1861) La Turquie En 1861, Paris. 
Muzaffer BAŞKAYA, “ Trabzon İlini Kalkındırma Cemiyeti’nin Kuruluşu Faaliyetleri ve Bu Kapsamda Ortaya Çıkan Bir Mahalle: Kalkınma Mahallesi”, Mavi Atlas, 7(2)/2019: 321-337

ISSAWI, Charles (1988), "Tebriz-Trabzon Ticareti 1830-1900 Bir Yolun Yükselişi ve Gerileyişi”, Trabzon 1988, çev. Kudret Emiroğlu, Sayı 2, Ankara: Trabzon İli ve İlçeleri Eğitim, Kültür ve Sosyal Yardımlaşma Vakfı.

KAZGAN, Haydar -TOKDEMIR, Ertuğrul, (1997) “Trabzon-Tebriz Yolu”, Bir Tutkudur Trabzon, Yay. Haz. İ. Günday Kayaoğlu-Öner Ciravoğlu-Cüneyt Akalın, İstanbul: Yapı Kredi Yayınları.

KÜÇÜKUĞURLU, Murat, (2009) “Türkiye'de Livaların Vilayetlere Dönüştürülmesi, Cumhuriyet Tarihi Araştırmaları Dergisi, 5(10): 23-50, Ankara: Hacattepe Üniversitesi Yayınları.

KÜTÜKOĞLU, Mübühat S. (1988), “XIX Yüzyılda Trabzon Ticareti”, Ondokuz Mayıs Eğitim Fakültesi, Birinci Tarih Boyunca Karadeniz Tarihi Bildirileri (13-17 Ekim 1986), ss.97-131, Samsun.

LOWRY, Heat ve Feridun EMECEN, (2012) “Trabzon”, DİA, ss.296-301, İstanbul: Diyanet Vakfi Yayınları.

ÖKSÜZ, Hikmet (2006), "Birinci Dünya Savaşı Sırasında Rus Donanması'nın Karadeniz Limanlarını Bombalaması”, Uluslararası Trabzon ve Çevresi Kültür ve Tarih Sempozyumu 16-18 Mayıs 2006, Cilt 1, Yay. Haz: Mithat Kerim Arslan-Hikmet ÖksüzVeysel Usta, ss. 391-398, Trabzon: Türk Ocağı Trabzon Şubesi Yayınları.

TEKİNDAĞ, M.C. Şehabettin (1974), “Trabzon”, DİA, XII/1, İstanbul: Diyanet Vakfi Yayınları.

TEZCAN, Mehmet (2002), "İpek Yolu ve XIV. Yüzy1la Kadar İpek Yolu Ticaretinde Trabzon'un Yeri", Trabzon ve Çevresi Uluslararası Tarih-Dil-Edebiyat Sempozyumu 3-5 Mayıs 2001, Cilt:1, Yay. Haz. Mithat Kerim Arslan-Hikmet Öksüz, ss.71-90, Trabzon: Trabzon Valiliği İl Kültür Müdürlügü Yayınları.

TOZLU, Selahattin (2002), “Trabzon-Erzurum-Tebriz Yolu (XIX. Yüzyılda Sosyal ve Ekonomik Bakımdan Bir İnceleme)”, Türkler, Cilt 14, ss.481-492, , Ankara: Yeni Türkiye Yayınları.

YILMAZ, Özgür, (2009), "Karadeniz'in Uluslararası Ticarete Açılması", Uluslararası Sosyal Araştırmalar Dergisi, 2(7): 359-382, Ordu. 


\section{Ekler:}

\section{Ek 1.Trabzon'u Kalkındırma Cemiyeti’nin Kuruluşu İle İlgili Haber}

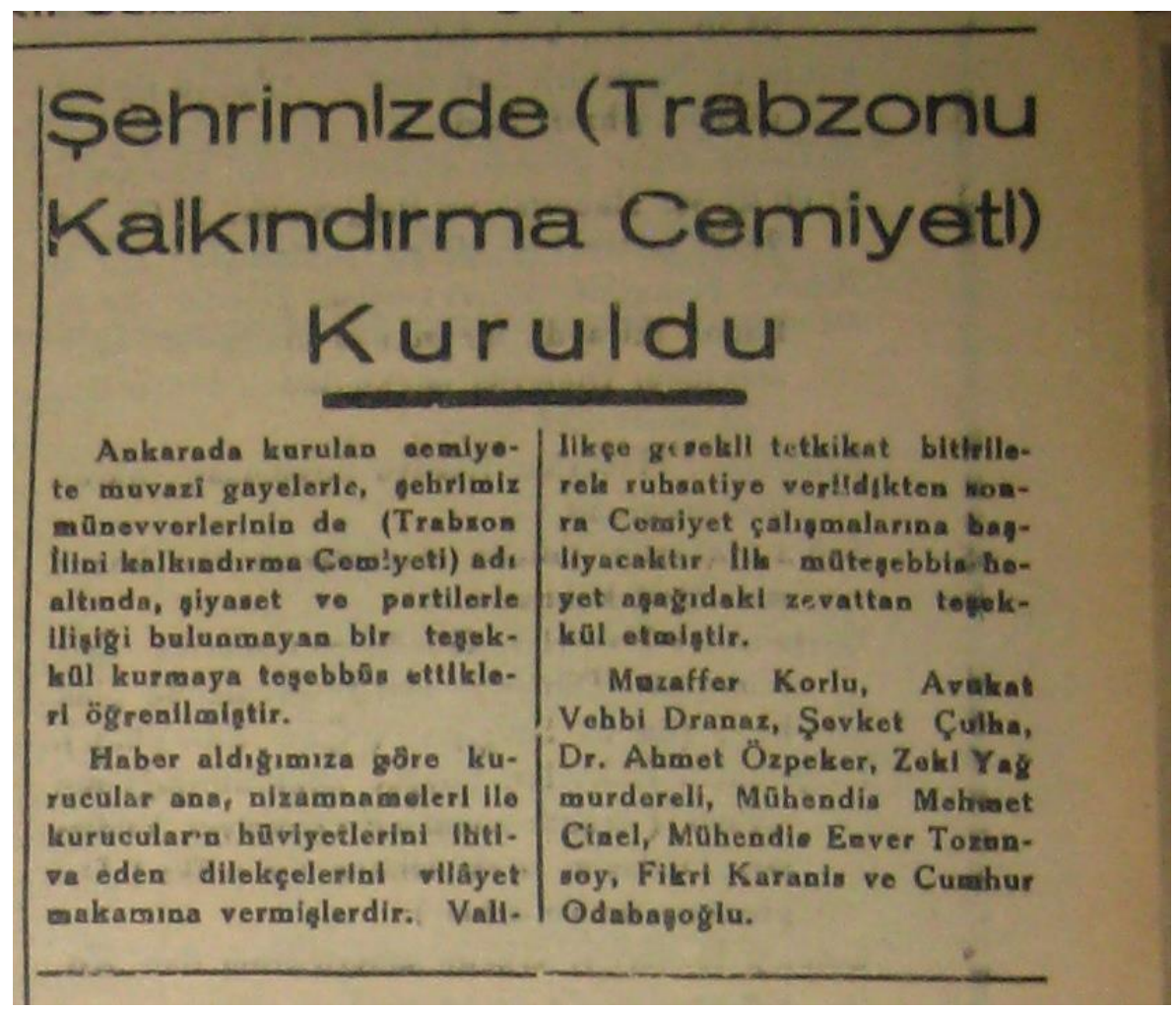

Ek 2. Trabzon İlini Kalkındırma Cemiyeti Üyelerinin Cumhurbaşkanı Bayar'ı Ziyareti

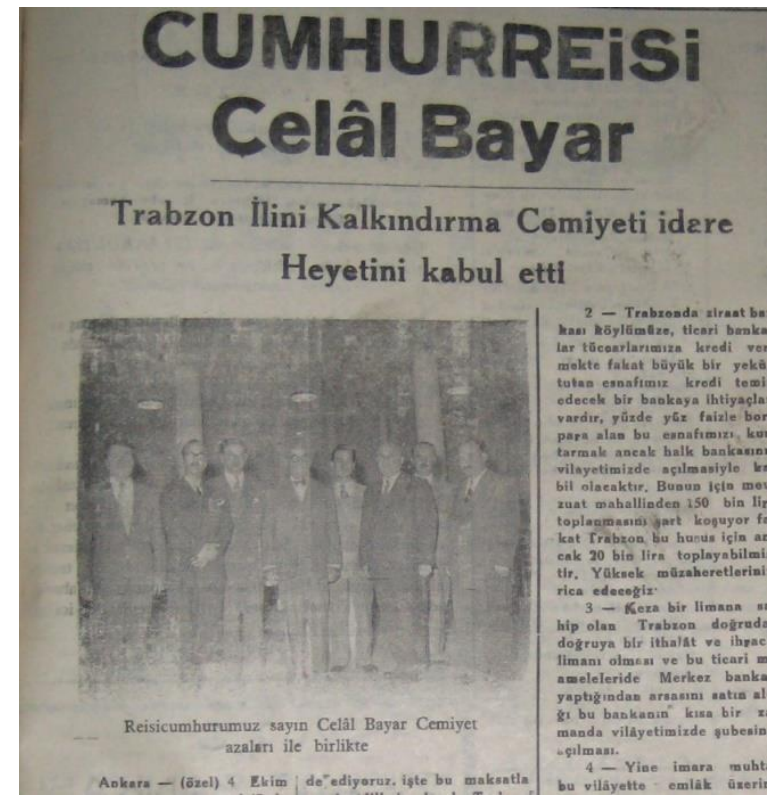


Muzaffer BAŞKAYA, “ Trabzon İlini Kalkındırma Cemiyeti’nin Kuruluşu Faaliyetleri ve Bu

Kapsamda Ortaya Çıkan Bir Mahalle: Kalkınma Mahallesi”, Mavi Atlas, 7(2)/2019: 321-337

Ek 3: Trabzon İlini Kalkındırma Cemiyeti’nin Kurduğu Kalkınma Mahallesi ile İlgili Bir Haber

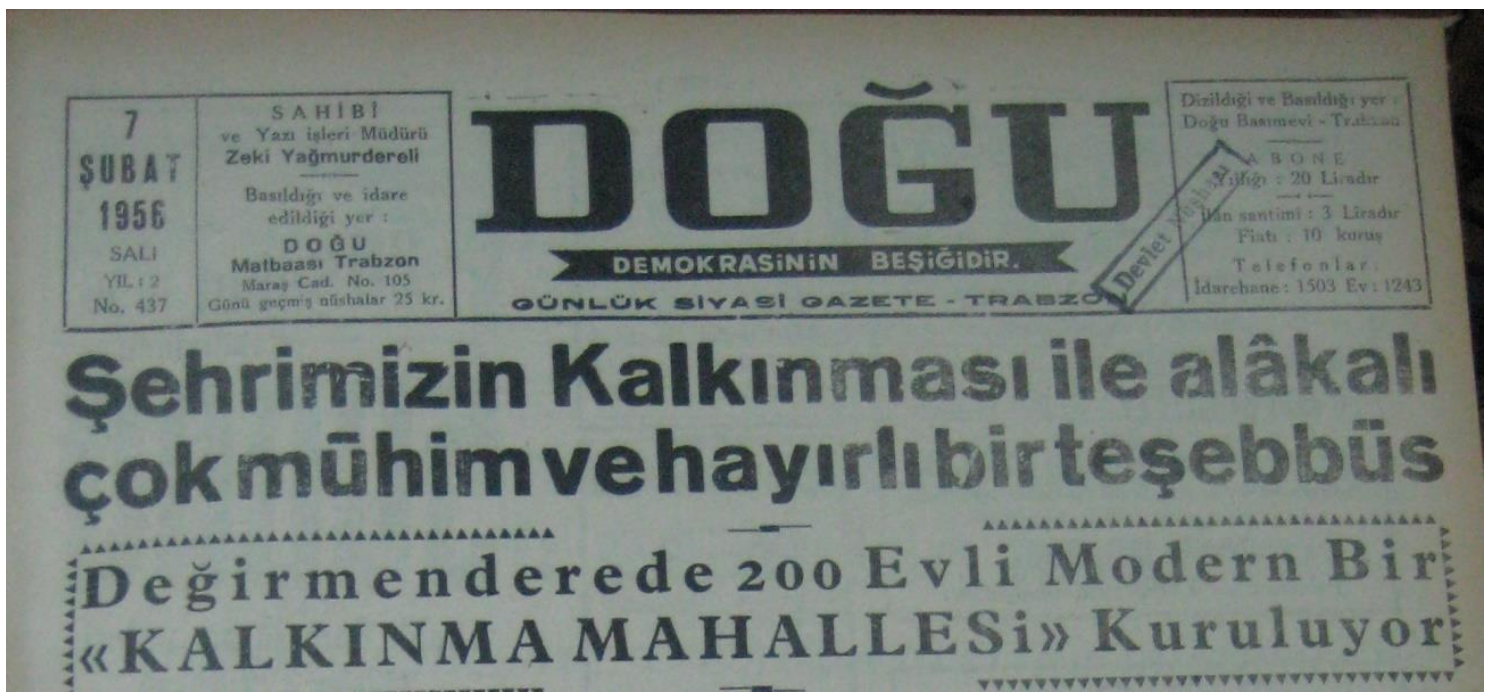

Ek 4: Trabzon İlini Kalkındırma Cemiyeti’nin Trabzon Halkına Bir Tebliği

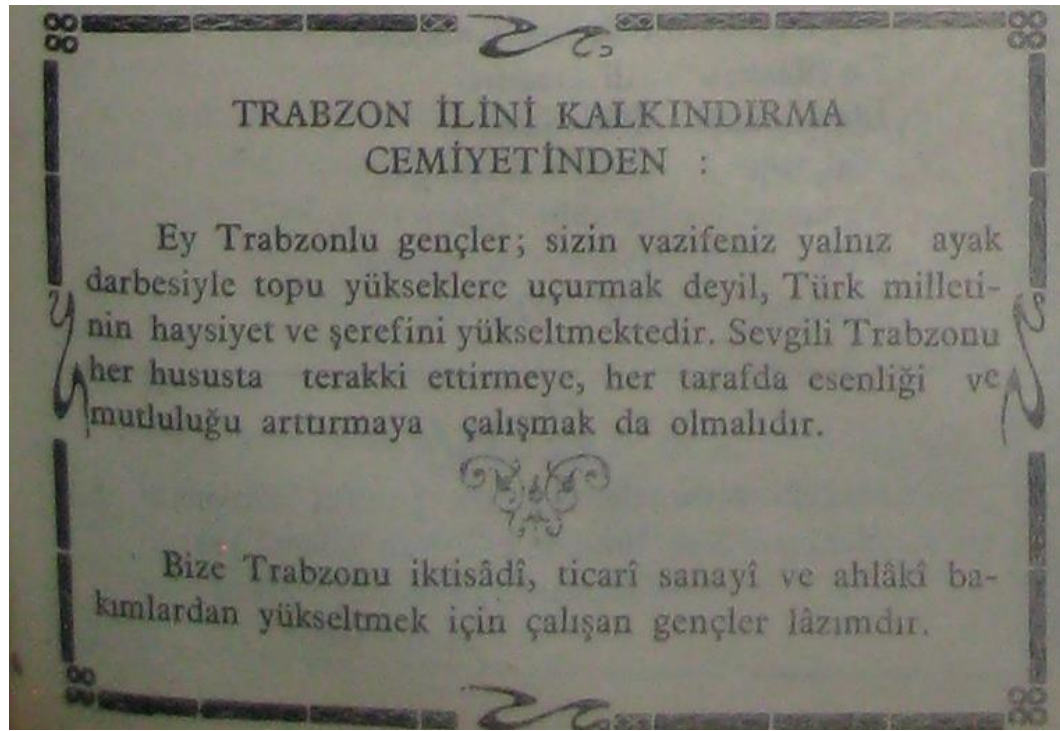

